\title{
AIR POLLUTION AND THE FILTRATION PROCESSING SYSTEMS FOR THE BITUMINOUS MATERIAL PLANTS
}

\author{
UDC 504.5:665.637.8
}

\author{
Dragan Jovanović ${ }^{1}$, Miomir Raos ${ }^{2}$, \\ Milena Jovanović ${ }^{2}$, Milena Medenica ${ }^{2}$ \\ ${ }^{1}$ Faculty of Mechanical Engineering, University of Niš \\ ${ }^{2}$ Faculty of Occupational Safety in Niš, University of Niš
}

\begin{abstract}
It is known that particulate matters of different granulations are one of the most important air and environmental pollutants, in general. This paper presents a prototype system for filtering particulate matter from extinguishing gases of a bitumen preparation plant using a "jet pulse" method for filter bags cleaning. For such type of filter plant, due to technological reasons, there is the need to create a shock wave which is required for the cleaning of the filter bags. The shock wave is generated by electromagnetic valves, whereas the tactile of the valve is determined by special controller depending on the type of filter, bags and air pollution. The result obtained through the use of special types of controllers allows the life span of the electric fan and the prevention of their overheating and damage.
\end{abstract}

Key words: air pollution, filtration, particulate matter, bituminous materials.

\section{INTRODUCTION}

The problem of air pollution has a significant impact on the environment and on human health in general. Air quality is influenced by concentrations of pollutants in the air, which are mostly derived from anthropogenic sources. In order to improve air quality the pollutants that are being monitored are carbon monoxide, carbon dioxide, nitrogen oxides, sulfur dioxide as well as particulate matter.

Concentrations of pollutants, such as nitrogen oxides, carbon monoxide, carbon dioxide, sulfur dioxide and particulate matter determine the air quality of urban environments. It is important to say that concentrations of these pollutants, especially particulate matter, negatively affect the quality of life of sensitive groups such as children, the elderly and the sick.

Received July 11, 2017 / Accepted August 29, 2017

Corresponding author: Milena Jovanović

Faculty of Occupational Safety, Čarnojevića 10a, 18000 Niš, Serbia

E-mail: milena.jovanovic@znrfak.ni.ac.rs 
The concentrations of pollutants in the air are largely derived from anthropogenic sources. The increase in the number of inhabitants is conditioned by the growth of urban environments, infrastructure, communication and road network, and therefore the need for increased use of bituminous materials, especially asphalt. Such a trend conditioned the construction of an increasing number of asphalt bases for processing bituminous materials and the production of asphalt as final product.

Asphalt bases of the older generation, which are most commonly used in developing countries such as Serbia, are large pollutants, and these pollutants emit even more pollutants (powders, sulfur oxide, nitric oxide, carbon oxides) during the production of asphalt mixtures, especially at the place of installation.

Over the last three decades, public attention has been focused on environmental pollution and hence on air pollution, which has led to the need for new environmental laws. Serbia is working hard in this field, trying to adapt its standards to the standards from the European Union. Air pollution is regulated by laws and by-laws in Serbia: the Law on Air Protection ("Official Gazette of the Republic of Serbia" No. 36/2009) [1] and the Regulation on conditions for monitoring and air quality requirements ("Official Gazette of the Republic of Serbia", No. 11/2013) [2], where, among other things, the limit and tolerant values of concentrations of pollutants, measurement period, measurement methodology, etc. are given. [3]. In order for the existing and newly constructed plants to respond to the given air quality requirements, there is a need for technologies that will allow air to emit air from the concentrations of contaminants within the prescribed values. One of the pollutants that affecting air quality the most are particulate matters regardless on granulate (PM10, PM2.5, TSP). The prescribed limit value for the concentration of particulate matter in the exhaust gases at the plant for the preparation of bituminous materials for the construction of roads (asphalt bases) prescribed by the Regulation [1] is $20\left[\mathrm{mg} / \mathrm{m}^{3} \mathrm{~N}\right.$, with the need for the installation of an appropriate technical treatment plant exhaust gases.

The practice so far has shown that the emission of particulate matter can't lead to proper values by the installation of cyclonic systems only, which required the necessity of developing and using filter systems. The division of filter systems can be carried out according to different criteria. One of the basic criteria is the technical solution for discharging filter bags, where three types of discharge are most commonly used: jet-pulses, fan shake and mechanical shake of filter bags. The so-called jet-pulse filters, with jet-pulse effect, yielded the best results, with the shaking of the filter bags being carried out by a shock wave of compressed air. Electromagnetic valves for the formation of a shock wave are installed in this form of the filter systems, while the valve tact is determined by a special controller depending on the type of filter, bag, as well as the concentration of the powder substance or the technical specifications of the given plant.

\section{BITUMENIZED MATERIALS AND ASPHALt BASES}

Asphalt base is a plant for the production of asphalt mass (asphalt), which is used for the production of carrier layers of roads, airport runways, parking plates, factory yards and other surfaces, which possesses certain characteristics in terms of quality and composition of stone mixture, asphalt mixing, etc.

Depending on the purpose, various recipes in the production of asphalt are used, which include the use of the following materials: 
- aggregates of 0-32 mm

- bitumen of various types (bit 45, 60, 90, 120, polymer, etc.)

- fillers (stone flour or own filler obtained from the pollination system)

- various additives in the form of powder or liquid materials (elastomers, polymers, etc.).

Usually the asphalt mixture is made by hot method in an asphalt plant (asphalt base) by the rock material being heated, dried and mixed with bitumen according to a particular recipe, defined by the temperature and the rate of mixing. The components of the asphalt base are also tanks for bitumen, silos for stone flour (filer) and the dump of aggregates.

Asphalt bases of the older generation are large air pollutants, as the production of asphalt mixtures results in the emission of various gases containing powdery substances, sulfur oxides, nitrogen oxides, carbon oxides, etc. The greatest pollution occurs in the processes of drying and heating of mineral aggregates due to technical and technological obsolescence.

\section{FILTERS PLANTS}

Contemporary asphalt bases in addition to the mentioned basic parts also have numerous systems for filtration of waste gases whose role is to retain the pollutants. The fact is that the concentrations of emitted pollutants from asphalt bases regularly exceed the permitted values and that the application of filtration systems is mandatory. The division of filter plants is carried out on the basis of different criteria: air flow, type of filtered substance, work principle, process parameters, etc. One of the most abundant systems for filtration of waste gases from asphalt bases, in addition to cyclonic systems, is a filter plant that uses filter bags. The use of filter bags means periodic cleaning and replacement.

The most frequent cleaning procedures for filter bags are: jet-pulses, ventilation shaking and mechanical shaking of filter bags.

Each filter system has two sides, the so-called "dirty" and "clean" side. The entry of "dirty" air and the purified air outlet are usually located on the opposite sides of the filter plant, and the filter filler itself in the form of filter bags is located between them, while the powdered substances are kept on filter bags [4]. A schematic view of the analyzed filter plant including the stream of "dirty" air through the "jet-pulse" filter is given in Fig. 1.

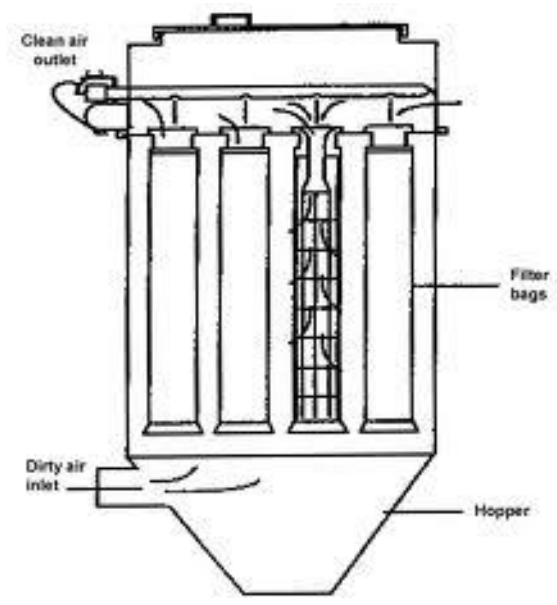

Fig. 1 Air flow through the "pulse jet" filter 
The technical solution of a single filtration plant depends primarily on the pollutant that is dominant in the technological process, then on the filtered airflow, the desired outlet air purity, etc. The problem that arises in the expansion of the filtration plant in technological processes in which the flow of "dirty" air is large (it amounts to several tens of thousands of cubic meters per hour), and in which large amounts of powdery materials are generated, is to quickly stick to the filter bags a large amount of powdery materials, with the filter ceasing to perform the purification function. In this case, there is an increase in resistance to air movement and congestion of the filter itself. In order to solve this problem, it is necessary to shake the filter bags on which the deposited powder particles are separated from the waste gas stream. The method of shrinking the filter bags with the "jet-pulse" effect is reflected in the impact wave of the air produced by a pulsed air release at a pressure of 0.5-0.6 [MPa]. The air is passed through the holes of the pipes, which produces the Venturi effect and the rapid spread of the bag, which causes the removal of powdered materials from filter bags (Figure 2) [4].

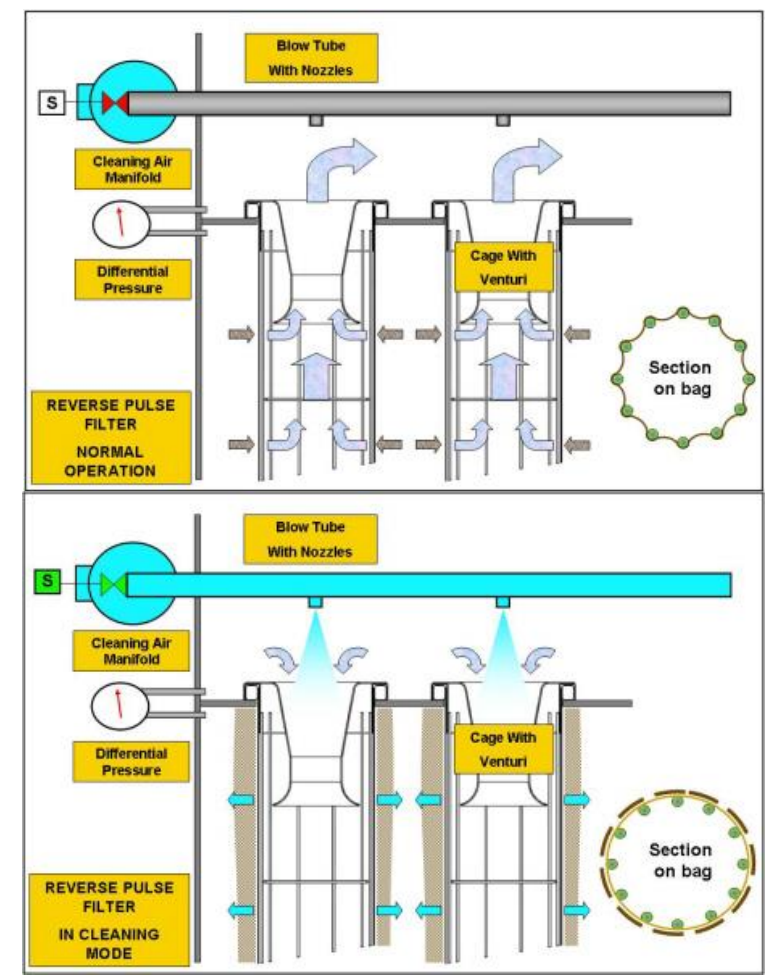

Fig. 2 "Pulse jet" filters

The quality of the filter operation depends largely on the cycle that defines the time of air leakage through the valve and the start-up time of the valve. Figure 3 shows the real filtration plant discussed in this paper.

In addition to the problem of the exploitation of asphalt bases is also the fact that the ambient air parameters change swiftly during the day, from early morning when the air is 
cold and wet until late in the evening. In the drying material for the production of asphalt mass, there is moisture that comes to the filter bags, whereby the powder particles of the larger granulate (in the form of tiles) are formed, and then it is necessary that the shifting time, or the activation time of the solenoid valve, be longer. This ensures more efficient sanding of the filter bags.

During the day, the amount of moisture decreases and it is necessary that the shrinkage time be shorter, since the formation of these larger granulate powders does not occur. Less granulation of the powdery materials quickly fills the pore of the filter bags. In order to separate the powder matter, they must have certain weight. Otherwise, the air current carries the powder material to the outlet of the filter bags.

It is concluded that the setting of the opening time of the valve is the most important segment in the efficiency of filter bag filtering. This implies the optimization of the process of opening and closing electromagnetic valves and the formation of impact waves, as well as the frequency of shifting in order to achieve the efficiency of the operation of the filter plant.

The process of shaking the filter bags implies a slower operation of the fan and the activation of the "jet pulse" effect for a certain time. The time of shaking the filter bags is determined experimentally and depends on several factors, mostly on the type of industry in which the filter plant is applied. It is usual that the time of shaking the filter bags is from 20 to 30 minutes, without the suction fan. It is also necessary that all dust be evacuated from the collector, which is achieved by the operation of a worm conveyor that removes collected dust from the collector further into the disposal system or to the recycling system. In order to enable the highest efficiency of the filter plant and the greatest energy savings, a control unit which operates electromagnetic valves at a certain time is introduced.

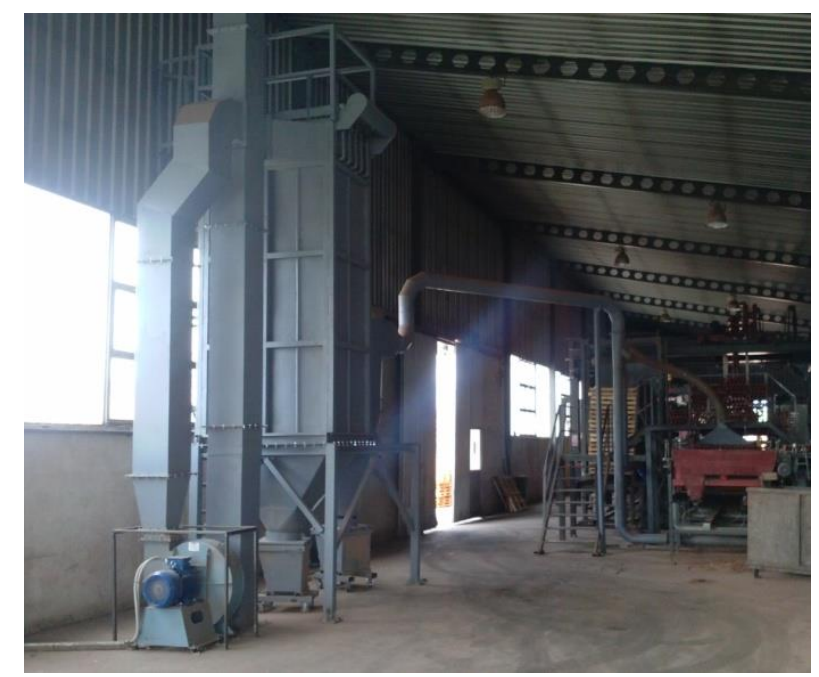

Fig. 3 Layout of the filter system applied to the system for the preparation of bituminous materials for road construction 


\section{CHARACTERISTICS OF THE CONSIDERED CONTROLLER}

These problems and the explication requirements of these and similar filter systems have led to the use of intelligent controllers based on the PIC controller. The microcontroller of Microchip from the PIC18F series, which is characterized by high stability and reliability, has been used as the basis for the production of controllers in air purification systems.

Basic characteristics that this microcontroller has are given in Table 1.

Table 1. Basic characteristics of microcontroller Microchip from the PIC18F series

Wide range of power supply voltage of 2-5.5 [V]

Priority levels of interrupts

The possibility of reprogramming the EEPROM memory up to 1000000 times

Four timer modules: an eight-bit and 1-3-sixteen-bit

13-pin connector that can be used as a 10-bit A/D converters with programmable acquisition time

Storage FLASH and EEPROM data for more than 40 years, the absence of power

100000 times reprogramming FLASH memory

Flexible oscillator structure with 4 modes of crystals, including high-precision PLL, two external Clock modes up to $48 \mathrm{MHz}$, internal oscillator block which provides 8 user defined frequencies from $31 \mathrm{kHz}$ up to $8 \mathrm{MHz}$, Fail-Safe Clock Monitor that allows safe shutdown if failure occurs in the oscillation

Controller fully automates the entire system for the air purification, operates with a programmed order of inclusion and exclusion of relevant electro-pneumatic valves within specific time points and on/off switch of respective electric motors that are present in the system as well as the collection and processing of information from the pressure sensor in order to control contamination (congestion) of the filter bag.

Requirements that must be fulfilled by the controller are:

- Stability and reliability and insensitivity to industrial disturbances;

- Complete programmer must be enclosed in the appropriate box with an appropriate level of protection that prevents the ingress of water and dust within it;

- Must have a simple form of entry and saving of the required parameters from the program menu. The considered controllers are all implemented with three 7segment display and three buttons with the appropriate protective foil, normal work has indication on the display that the process is underway in the form of floating "g" segment on 7-segment display and visual display, printing of a current electro-valve which is activated by the controller;

- Must be adaptive in terms of expanding the number of outputs that can be easily upgraded, with additional output modules it becomes easy to set up on existing board. The expansion in terms of the numbers of outputs should be unlimited and only depend on the specific requirements. With this controller programme, the user can easily reprogramme the required number of output channels;

- All outputs to electro valves should be electricity limited and protected against permanent short circuit; 
- Each of the outputs to the electro-valves should have a specially adapted form of the output signal, which at first, reaches a value of supply voltage of electropneumatic valves and then falls to the voltage that provides safe keeping of valves open since the valves are made with small intermittence. Without these features, solenoid coils would quickly overheat and would be permanently damaged. This is also one of the main reasons why it is not used on conventional PLC;

- All input and output pins of the microcontroller must be separated by suitable optocouplers to reduce the influence of noise on the work of the microcontroller, which is also the galvanic protection to the microcontroller from every possible high voltage that would appear in the operating conditions to the voltage of 5000 [Vrms ];

- The controller must have on the side of the network built-in surge protection above 275 [V] and current electrical protection up to 6500 [A] so that the possibility of penetration of high voltage under the influence of lightning is minimized;

- Depending on the application, in certain degrees of automation of installations there should be more or less options for user programming in order to accommodate specific application of programmer. In this regard, the programming may include the following options:

- Programming of the duration of the signal (typically limited between 5 [ms] and 5 [s] setting of $0.05[\mathrm{~s}])$

- Programming of the pause duration (typically limited between $1 \div 999$ [s] setting of $1[\mathrm{~s}]$ )

- Programming the number of channels depending on their needs

- Programming the number of cycles of electro-pneumatic valve, before the automatic starts "turning off" the individual processes after pressing the key for turning off so that the whole process would be properly excluded. After pressing a key to turn off, appropriate blinking signal lights are activated as visual indication of the system stopping. The bulb flashes until automatics perform the necessary sequence and turn off everything. Also, the display on the 7-segment display controller changes from the moment of turning the key "STOP", keeping the current cycle number that was left to the complete exclusion;

- Choice of using analog or digital inputs for monitoring pressure sensors. Setting parameters are in relation with the corresponding type of input in order to properly manage the channel.

The pressure sensor is used to supervise the moment when bags that are used for the air purification, be sufficiently fouling in order to then activate the electro pneumatic valves which would make their cleaning and thereby saving of electrical energy.

The whole system has a power block that includes the corresponding energy cabinet through which the controller manages the appropriate contacts which control the present electric motors. The closet has switches and buttons which enable manual and automatic operation, while each of the motors has adequate electrical protection.

As the objective is to provide as simple as possible controller, it is considered that this is achieved because both regimes and the "automatic operation" and "manual mode" are easy to manipulate in operating conditions, where the mode "automatic operation" of the system is based on the fact that the cam switch is set to "Automatic mode" and then after pressing START button, the controller take further control of the complete inclusion of particular sequences and the electric motor. "Manual mode" operation is foreseen for the possible need for servicing process where it is possible with manual control, switching of 
individual motors as well as reprogramming the controller. A schematic view of such a controller is shown in Figure 4.

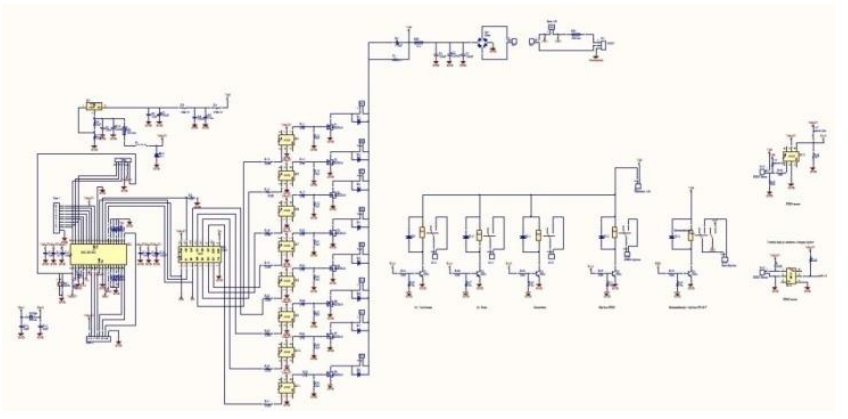

Fig. 5 Schematic representation of PIC controllers

\section{CONCLUSION}

From everything attached it is shown that the need for such filtration systems is large in all parts of the industry that generates particulate matter, not according to the prescribed limit and tolerant values of concentrations of particulate matter in a given industry. Today, each system tends to be easy for use, and from the above, a controller based on PIC provides that such filter installation can be used and that is presented in the paper. The main difference why a microcontroller and not a classic PLC controller has been used is a fact that each of the outputs to the electro-valves has a specially adapted form of the output signal which at first reaches a value of supply voltage electropneumatic valves and then falls to the voltage that provides safe keeping of valve, since the valves are made with small intermitancom. Without these features, solenoid coils would quickly be overheated and permanently damaged.

Acknowledgment: This paper is a part of the project "Improvement of the monitoring system and the assessment of a long-term population exposure to pollutant substances in the environment using neural networks" No. III 43012 at the University of Niš, Faculty of Occupational Safety in Nišs, and was supported by the Ministry of Education, Science and Technological Development of the Republic of Serbia.

\section{REFERENCES}

1. Regulation of limit values for emissions of air pollutants, Official Gazette of the Republic of Serbia No. $71 / 2010$ and $6 / 2011$;

2. D. Jovanović, S. Jovanović, M. Jovanović, S. Đukić, "Implementation of PIC controller in Air Purifying Systems", Proceedings of the XII International Conference on systems, automatic control and measurements, SAUM, pp 128-131, 978-86-6125-11

3. Low for air protection ("Off. Gazette of RS", No. 36/09);

4. Daniel Vallero, "Fundamentals of air pollution", 2014.

5. Chuck Hellebuyck, "Programming PIC Microcontrollers with PICBASIC", A volume in Embedded Technology, 2003, pages 112-132 
6. K. Ellithy, S. Said, O. Kahlout, "Design of power system stabilizers based on $\mu$-controller for power system stability enhancement", International Journal of Electrical Power \& Energy Systems,Volume 63, December 2014, Pages 933-939

7. Tim Wilmshurst, "CHAPTER 12-Some PIC microcontroller advances", Designing Embedded Systems with PIC Microcontrollers (Second Edition), 2010, pages 371-389.

8. V. Tasić, B. Maluckov, T. Apostolovski-Trujic, R. Kovačević, M. Živković, I. Lazović, "Particulate matter (PM10 and PM2.5) concentrations in naturally ventilated offices in Bor, Serbia", Facta Universitatis, Series: „Working and Living Environmental Protection“, Vol. 12, N³, 0354-804X (Print), ISSN 2406-0534 (online),

9. N. Živković, N. Mišić, M. Jovanović, "Comparative analysis of the concentration of ambient air pollutants determined by measuring and modeling”, Facta Universitatis, Series: „Working and Living Environmental Protection“, Vol. 11, №2, 0354-804X (Print), ISSN 2406-0534 (online),

\section{ZAGAĐENJE VAZDUHA I SISTEMI ZA FILTRACIJU KOD POSTROJENJA ZA PRERADU BITUMENIZIRANIH MATERIJALA}

Poznato je da su praškaste materije različite granulacije jedni od najznačajnijih zagađivača vazduha $i$ životne sredine uopšte. U radu je posmatrano jedno prototipsko postrojenje projektovano za filtraciju praškastih materija iz izduvnih gasova postrojenja za pripremanje bitumeniziranog materijala, kod koga je primenjen ,jet puls" način čišćenja filterskih vreća. Kod ovakvog tipa filterskog postrojenja, iz tehnčko tehnološkog razloga, javlja se potreba za formiranjem udarnog talasa, radi čišćenja filterskih vreća, udarni talas stvara se primenom elektromagnetnih ventila a takt ventila određuje poseban kontroler u zavisnosti od vrste filtera, vreća i zaprljanosti vazduha. Rezultat dobijen upotrebom posebne vrste kontrolera omogućava duži radni vek elektroventila $i$ prevenciju od njihovog pregrevanja i oštećenja.

Ključne reči: zagađenje vazduha, filtracija, praškaste materije, bitumenizirani materijal 